PRIFYSGOL

glyndŵr

Glyndŵr University

Glyndŵr University Research Online

Theology

Theology

$1-1-2003$

\title{
Empirical theology: a natural development?
}

William K. Kay

Glyndwr University, w.kay@glyndwr.ac.uk

Follow this and additional works at: http://epubs.glyndwr.ac.uk/theo

Part of the Religious Thought, Theology and Philosophy of Religion Commons

Journal compilation ( $) 2010$ Trustees for Roman Catholic Purposes Registered. This article was published in The Heythrop Journal in 2003 published by Blackwell Publishing - Wiley. This is the author's final post print version. The definitive version is available at www3.interscience.wiley.com

\section{Recommended Citation}

Kay, W. K., (2003)'Empirical theology: a natural development?'. The Heythrop Journal, 44(2), 167-181

This Article is brought to you for free and open access by the Theology at Glyndŵr University Research Online. It has been accepted for inclusion in Theology by an authorized administrator of Glyndŵr University Research Online. For more information, please contact d.jepson@glyndwr.ac.uk. 


\title{
Empirical theology: a natural development?
}

\author{
Revd Dr William K Kay \\ Senior Lecturer in Religious and Theology Education, King's College, London and \\ Director of the Centre for Pentecostal and Charismatic Studies, University of Wales, Bangor \\ Address for correspondence \\ w.kay@glyndwr.ac.uk
}

\begin{abstract}
Empirical theology is distinguished from practical theology by reference to the views of Duncan Forrester and $\mathrm{J}$ van der Ven. The nature and historical emergence of theological disciplines are considered and related to the social science methods found in van der Ven's account of empirical theology. Such social science methods are congruent with those used in natural sciences and therefore in natural theology. Empirical theology may be variously located within the whole enterprise of theology. Yet, it belongs in the theological fold by virtue of its relation to natural theology and through the historical trajectory by which the subdisciplines of theology have come into being.
\end{abstract}

\section{Introduction}

Following the case made by Hirst, and supported by cognitive psychology's work on schemata, academic disciplines may be delineated by their characteristic concepts and methods. ${ }^{1}$ Mathematics is inconceivable without the concept of number or the rules by which numbers may be manipulated. Physics is inconceivable without the concepts of mass, energy and force, and the methods by which these concepts are determined, related and predicted. There may well be relationships between the methods of one academic discipline and another 
for reasons arising from the nature of knowledge or the structure of the external world. Yet, there will also be methods specific to the concepts within a particular discipline because these methods are congruent with those concepts. The methods applicable to the discipline of history, for example the assessment of the bias of original documents, would hardly make sense within the discipline of physics.

So, while disciplines may be discrete and concerned with their own internal problems, they may be grouped together within larger entities subordinated to general purposes. These larger entities are fields. For example, education may be described as a field whose general purpose is the transmission of worthwhile knowledge to pupils by rational and ethical means. This field may draw upon educational psychology, ethics, philosophically-based distinctions between different forms of knowledge, and other elements drawn from political discourse. As a field it is too variegated and wide to be reduced to a discipline. Yet there is sufficient coherence among the contributory disciplines for the socially recognised enterprise of education to be expressed institutionally.

\section{Practical or empirical theology}

Practical theology can be understood as a field. It is true Forrester describes practical theology as 'an academic discipline' but his classificatory scheme is only intended to explore how historically the various components of theology have been related to each other within the university context. ${ }^{2}$ He does not draw the distinction made here between disciplines and fields. Nor does he draw a sharp distinction between science and other forms of human activity. For him science is simply knowledge systematically obtained rather than knowledge obtained by specified methods. And, where theology (especially in Germanic debate) claimed to be a science, it did so in order to justify its place within the university curriculum. What 
Forrester shows is the way that practical theology has existed within theology since the Middle Ages, either implicitly as 'essentially a devotional exercise' or explicitly as the last stage of theological education. It is no surprise that practical or pastoral theology was recognised in Tübingen as early as 1794 .

For Forrester, and for the theologians he briefly surveys (Schleiermacher, Barth, Rahner, Hiltner, Pannenberg), a discipline is rigorous, careful and systematic. It is a discipline precisely because it requires intellectual discipline on the part of its practitioners. Consequently practical theology, if it is to be a discipline, cannot in Forrester's words be a 'lose amalgam of skills-directed discussions... (and) sloppy thought' (page ix). Rather practical theology is the application of theologies, whether liberal or conservative, to the practical concerns of the church. So it is not the kind of theology that is carried out that defines practical theology. Nor is the kind of practice that is carried out that defines practical theology. Rather it is the detailed and rigorous combination of these two elements that comprise its definition.

A second method of locating empirical theology has emerged through the Dutch University of Nijmegen. Building on the five volume handbook of pastoral theology edited by Karl Rahner and others and published in 1964 the faculty of theology at Nijmegen initiated a two-phase model of pastoral theology in which the first phase constituted a social-scientific description and analysis of pastoral themes and the second phase constituted theological reflection. ${ }^{3}$ This two-phase model was eventually abandoned for three main reasons. It was thought that social-scientific research is inadequate for dealing with pastoral and ecclesiastical problems; the method of theological reflection within the second phase was insufficiently defined; the 
differences between the social sciences and theology in relation to their respective formal subjects and, consequently, the paradigms they elicit are too great.

As a result the Nijmegen department of pastoral theology shifted from a multidisciplinary to an intradisciplinary approach. By this they meant that, in general, the methodology of one discipline, here the empirical sciences, was adopted by another, in this case (pastoral) theology. So after 1975 theologians began to apply empirical research to the problems and issues of pastoral theology in order to describe them from a theological point of view. The justification for this procedure was that theology had always made use of the methods of other disciplines for its own purposes. For instance, philological analysis drawn from elsewhere in the academic spectrum had been used to scrutinise canonical texts. If theology appeared to be acting imperialistically, that at least was its regal privilege.

The two-phase process gave way to a multiple process, involving four or five phases. The revised form of practical theology entails theological reflection upon a particular theological problem, the translation of this problem into empirical terms, the testing of these terms and, finally, a theological evaluation of, and reflection on, the results of the empirical work. Theology begins and ends the process. Conceptualisation and testing which occur in the middle are empirical. By 1985 the intradisciplinary multi-phase approach to pastoral theology came to be called 'empirical theology'.

This nomenclature had been deliberately borrowed from German Protestant theologians in the late 1960s who had, in their turn, made use of the writings of the Chicago School from the period immediately following the First World War. Empirical methods had been used for the analysis of situations requiring ethical judgments and in relation to the interface between 
clinical and pastoral work. According to van der Ven the relationship that emerged in United States between empirics and a range of disciplines needs to be understood against the background of the influence of William James and John Dewey, and even John Locke. ${ }^{4}$

In the context of this discussion the location of empirical theology within intradisciplinary work implies that theological method is not unique to its subject matter. Theologians are able to use social-science methods as a way of theologising. These methods become theological simply because they are in the hands of theologians and because their object is human faith. Van der Ven is clear about this. 'The direct object of empirical theology is not God but rather human experience of God, our communication with him and about him...the very object of empirical theology... [is] the quality of the relationship between God and man...the direct object of theology must be our experiential knowledge of God...the direct object of theology is faith, the indirect object God' 5 Empirical theology can only address God indirectly since revelation is embedded in human experience.

What hangs on the distinction between interdisciplinary and intradisciplinary approaches? If an approach is interdisciplinary, then the disciplines of both contributing subjects may be brought to bear upon the resultant product. If it is intradisciplinary, then the decisive issue is at the interface between the two disciplines which are, effectively, treated as one. And they are treated as one because theology is not strictly speaking treated as a discipline but rather as the Christian community's tradition of thought and action. So van der Ven gives clear guidance about the application of empirical methods to the conduct of empirical research, even to the extent of recommending $\mathrm{p}$ values and alpha coefficients, but much less guidance about theological reflection and interpretation. 


\section{The interrelation of theological disciplines}

But how should the different disciplines in theology be related to each other? Here are two ways. In the first they are arranged in a spectrum such that the different disciplines are placed next to each other in approximate order of similarity. Thus dogmatics might be placed next to historical theology on one side and ecclesiology on the other. These three disciplines are related very directly to the church. On this spectrum would be placed empirical theology and it would be seen as a theological discipline carried out on a wide range of theological topics and contributing to the whole field of theology. Connected with all these disciplines would be practical theology, for practical theology would be thought of as the application of theology of all kinds to the activities of the church in its widest sense. Practical theology would, therefore, be related to dogmatics and empirical theology as much as to biblical studies. It would be the applied element in each discipline and because it is made up of all the theological disciplines would constitute a field.

Alternately we could place empirical theology in a position intermediate between all the other disciplines and practical theology. In this sense empirical theology would be seen as largely methodological in its distinctiveness. Its task would be to take the concepts and problems of the other theological disciplines and to test and apply them to current populations. It would prepare and re-shape other theological disciplines in readiness for their practical usage within the various communities to which theology speaks.

Of course, empirical theology would have considerable difficulty in relating itself to some theological disciplines. Within historical theology there are few if any concepts that can be operationalised. Similarly empirical theology would have no purchase on debate concerning the ontology of the Trinity, for example, since the procession of the Holy Spirit is not 
susceptible to empirical investigation. Yet, although empirical theology could not contribute to the development of these disciplines, it would still be able to contribute to their application and formulation. ${ }^{6}$

Does this arrangement of theological disciplines either in relation to practical theology directly or in relation to practical theology through the mediation of empirical theology have any implications for the connection of these disciplines one with another? Can we suggest how systematics might be related to biblical studies, for example? Here it has to be said that the main way the different disciplines of theology might relate to each other concerns which one is given priority and which ones are used evidentially. Barth's Church Dogmatics is a systematic work, yet it certainly draws upon biblical and historical theology though the discussion drawn from these disciplines is symbolically carried out using a smaller font size. The same kind of shifting balance might occur if historical theology were the prime focus of the writer. Here historical doctrines would be discussed and interrelated and the systematic or biblical contributions to these doctrines would be contributory and evidential - in a smaller font.

\section{Methods of empirical theology}

The location of empirical theology in relation to theology as a whole and its characterisation either as interdisciplinary or intradisciplinary have an important bearing on the criteria by which work of this kind is assessed. Kay and Francis distinguish between interdisciplinary inquiry in which the content of one discipline is reassessed in the light of another (as when chemical reactions might be reassessed in the light of changes at sub-atomic levels registered by physics), the amalgamation of two disciplines into one new discipline (as with the combination of sociology and psychology into social psychology), and the form of 
interdisciplinary inquiry in which the practitioners of both disciplines are satisfied that a piece of research is valid from their own point of view. ${ }^{7}$ They argue that only the third form of interdisciplinary inquiry is completely satisfactory because it is the most stringent. It requires all valid pieces of work to fulfil two sets of criteria. They do not specifically discuss intradisciplinary work. Nevertheless, the Nijmegen school's approach is largely covered by putting their first two concepts of interdisciplinary enquiry in sequence.

If Forrester's looser notion of an academic discipline is accepted, practical theology will be systematic and rigorous without necessarily following the canons of any self-conscious methodology. If van der Ven's notion is accepted, then practical theology is fundamentally answerable only to the methodological procedures inherent in social science investigation. Granted, this investigation will be handled sensitively and by theologically knowledgeable practitioners, but the actual criteria by which work is judged will be empirical rather than theological. This is because in van der Ven's scheme the process of theological reflection is one that is the least answerable to methodological precision. Although he outlines how theological reflection might proceed, the outline has no hard and fast guarantee of quality built into it. Reflection is nebulous. It is not an activity that appears to have any precise outcome or associated procedure.

The operationalisation and testing of theological concepts, in theory, follows the same path as is followed whenever any intellectual concepts from any field of discourse are tested. The concept must be translated into operational terms, that is, terms susceptible to empirical address. For instance, pacifism exists as an intellectual construct but, for the purpose of empirical work, must be turned into a scale that can be used with human populations. Similarly theological ideas and concepts must be translated into scales or norms that can be 
reached by empirical methods. Suppose that one wanted to investigate the relationship between types of prayer and ideas of God, it would be necessary to devise operational variables based upon theologically derived concepts of prayer and of God and then, within specified human populations, to explore the relationship between them quantitatively or qualitatively.

What is being said here is that empiricism presumes a particular account of human beings and their relation to the external world. Empiricism presumes that human beings derive and abstract from the external world internal images and concepts -- indeed this process is accounted for in detail within the psychology of Piaget -- and that, conversely, images and concepts can be translated into actions within the world from which they ultimately came. This philosophical account of the world in which rational observers are distinct from the outer physical or social world dates back at least as far as the mind of Descartes. It presumes, but does not insist on, the commensurability of the internal and the external. It is rational but not rationalist. It can accommodate dialectic but it allows the last word in any argumentation to the concrete and measurable. It assumes that the external is transparently available without mediation to all human beings through their sensory apparatus. It is unable to appeal to any principle outside itself when arguments are advanced suggesting that apprehensions of the external physical or social worlds are distorted by, for instance, language or other media. And, when such arguments are advanced, as when it is asserted that there is no theory-free perception, then empiricism can only appeal to the perceptual agreement of numerous observers. Or, to put it another way, it can only insist that objectivity is found in multiple concurring subjectivities. 
Empiricism's philosophical base should not simply be equated with crude reductionism or with scientific positivism. The former usually reduces ideas or explanations to a simple material form (e.g. human love is only a series of chemical reactions). It is found most cogently expressed in the work of B F Skinner (1904-90) whose behaviourism scorns the reality of mental events and translates complex emotions into observable behaviours. The latter asserts that only a scientific method dependent upon measurement and testing can lead to knowledge, and that no other roads to knowledge exist. ${ }^{8}$ Consequently method, which itself can hardly be axiomatically justified, is given a place of pre-eminence. Empiricism, however, belongs to a much larger vision of humanity and certainly has no need to embrace reductionism. It does not need to deny the reality of unobserved entities like the human mind or imprecise ones like human emotions. Likewise empiricism has no need to be positivistic. Rather it embraces all that is available to, or deducible from, the human senses.

\section{Empirical theology, natural theology and objectivity}

At its simplest natural theology is the theology of the natural world. It is the theology of the universe as it lies around us. Yet, since this universe has been investigated so successfully by the methods of science, and these methods have revolutionised the paradigms by which we understand the created order, it is unsurprising that natural theology has been caught up within these transformations. It would be unthinkable now for natural theology to discuss the cosmos as if we lived in a heliocentric universe.

The methods of science which characterise physical sciences that probe the furthest corners of the created order are in many respects similar to the methods utilised within versions of empirical theology. In each case hypotheses are propounded, tests are initiated, data is 
recorded, probabilities are assigned and results are discussed. Van der Ven certainly accepts the view of science put forward by Popper, originally in relation to scientific discoveries within the physical world, but equally applicable to the social sciences. In short, these proposals entail the imaginative proposal of an hypothesis to explain a problem and the operationalisation of the concepts within the hypothesis so that it may be tested. This testing occurs by attempts at falsifying (rather than verifying) the hypothesis and, where falsification fails to take place, the hypothesis becomes a theory that is conditionally acceptable. ${ }^{9}$ The better the theory, the wider range of phenomena whose behaviour it explains.

This notion of science has the advantage of embracing continual change. It is progressive in the sense that the knowledge it offers is neither static nor absolute. It should be apparent at this point that the congruence in methods between empirical theology and the natural sciences is such as to create a unique relationship with natural theology. Empirical theology uses methods very similar to those used within the natural sciences and to which natural theology responds. For this reason the relationship between empirical theology and natural theology is a special one. Indeed, as is argued below, if natural theology is the theology of the natural and physical world, it also makes sense to conceive of natural theology as the theology of the social world in which human beings have always lived. And, as will also be argued below, it is a reasonable postulate that, just as the natural world speaks of the creative power of God, so also does the social world.

In considering theology as a science, it is necessary to engage with notions of objectivity that have been put forward within theological discourse. ${ }^{10}$ Barth especially discussed at length different types of objectivity and distinguishes clearly between a primary objectivity, that is, the knowledge of God held by God about himself 'God is objectively immediate to himself' 
and a secondary objectivity because 'to us' because 'he is objectively mediate' (Church Dogmatics $[\mathrm{CD}], 2,1,16) .{ }^{11}$ For this reason 'we really know him only in his clothed objectivity' (CD, 2, 1, 16). So, while it is perfectly true to say that from 'we have God as an object' (CD, 2, 1, 21), it is also true but God is an object different from other objects because grace is required for this apprehension. 'Only because God posits himself as the object is man posited as the knower of God' (CD, 2, 1, 22) or, again, 'his primary and his secondary objectivity is objectivity for us, since he himself makes himself into object for us and us into knowers of him' (CD, 2, 1, 23).

In short, Barth argues that, whereas the most perfect objectivity exists in the knowledge that God has of himself, a secondary objectivity exists in the knowledge of himself that God gives to human beings in grace. This knowledge is objective rather than subjective and by this Barth means that it is true, real, genuine knowledge and not delusional.

The use of the term 'objective' in Barth's vocabulary is related to the notion of an object, rather than a procedure by which agreement about perception might be reached. Objectivity appertains to the perception of an object by a subject. This notion of objectivity is certainly thought of as too simple in the scientific and philosophical community where objects are themselves problematised. This occurs most obviously in the physics of atomic and subatomic particles. The particles (e.g. protons, electrons, quarks) are unobservable and therefore imperceptible and, where observed by instrumentation, altered by the process of observation. $^{12}$ So, though protons, electrons and quarks are objects, they are not perceived as objects in the normal way. 
The placement of theology among the sciences must be understood as arising from a wish to secure the status and value of theological discourse. Historically it is true theology preceded science and its place within the university curriculum was secure from the Middle Ages to the Enlightenment. Theology provided the vision for society as well as an explanation of the way of salvation. It was made compatible with Aristotelian logic by Aquinas who also contributed to the integration of Aristotelian ethics with Catholic moral theology in such a way as to classify and systematise descriptions of $\sin$ and virtue. To say at any time before the Enlightenment that theology was a science would be to offer it no compliment. ${ }^{13}$ Only after scientific knowledge came to be seen as the paradigm of all knowledge (excepting perhaps mathematics) would any form of intellectual inquiry seek to emphasise its scientific credentials. So when Barth or Forrester speak about objectivity or, as Torrance does (see below), of 'theological science' the assertion they are making its to be understood in the light of the counter assertion that theology is not scientific in the slightest but is rather a species of art.

For, if theology is an art, it is merely a sophisticated means of myth-making for the purpose of providing meaning to human aspiration and emotion. ${ }^{14}$ It belongs with cave paintings and Stonehenge as well as with the ubiquitous narratives of origination that have sustained human beings in the face of hostile environments and intimations of despair. It is a means of domesticating contingency and inspiring morality. Yet, despite these grand ends, it is a series of pictures, images and stories that can claim no more validity than any product of the imagination. It is, at bottom, arbitrary and metaphorical. It has been constructed by human beings and may be changed by them because its account is non-realist and connects with no absolute being or divine authority. 
In categorising theology as an art or as a science in terms of $21^{\text {st }}$ century terminology one is placing it within a large frame of reference that is big enough to contain numerous academic disciplines and fields. For the purpose of this discussion, and in the context of the relationship between empirical theology and its purposes, theology is placed within the scientific frame of reference, even if such a placement is coupled with a recognition that theology has many features that cannot align it with the most hardline of the physical sciences.

\section{Natural theology and empiricism}

At its widest extent natural theology deals not only with the external world of the physical universe but also with the social world of human beings and the inner space of human psyche. Both Rahner and Lonergan in separate ways accept that unrivalled advances in scientific and social scientific knowledge are likely to enrich and add value to natural theology. ${ }^{15}$ Barth alone stands opposed to any compromise with natural theology.

Barth's condemnation of natural theology rests on at least three grounds. First, natural theology presumes a knowledge of God 'outside God's revelation in Jesus Christ' (CD, 2, 1, 168). Natural theology appears to offer knowledge of God outside the grace of God. It therefore negates grace and renders it unnecessary. It attempts to replace the divine work by human constructions. It is dangerous because it provides a substitute for the true knowledge of God given in revelation in Jesus Christ.

Second, natural theology in the broad sweep of its historical development led to the demands made by the Nazi party in 1933 that Adolf Hitler be recognised as 'a source of specific new 
revelation of God' $(\mathrm{CD}, 2,1,173)$ whose words took their place beside revelation attested in Scripture. This claim made by the Nazi party followed developments within the $18^{\text {th }}$ century when humanism was revived and within the $19^{\text {th }}$ century in the rise of romanticism that led to the subsequent ideals of national socialism. It rested on the assumption that God worked within culture and culture was gradually improving in accordance with the divine workings so as to culminate in what might be identified as the kingdom of God. For this reason there was an overall consonance between revelation and the social, the religious, the national and perhaps even the Germanic. It was the word 'and' to which Barth so vigorously objected. Nothing should be put alongside revelation, for revelation belongs in a class of its own needing neither social nor religious nor national nor Germanic support. This complex of ideas and this denial of natural theology were expressed in the first article of the Barmen Declaration in 1934 and declared by the Confessing Church.

Third, natural theology appears to offer a second source of truth to stand 'alongside and apart from the one Word of God' $(\mathrm{CD}, 2,1,176)$ with a consequence that, where there appears to be a disagreement between the two, one must be right in the other must be wrong. How is humanity to decide in such cases? If natural theology is indeed a means of obtaining knowledge of God, then why should its conclusions be set aside in the face of the different conclusions of revelation? Such a dilemma was, to Barth, intolerable and a further reason for holding fast only to revelation as the sole source of true knowledge of God.

Yet there is in Barth also the recognition that the biblical witness contains reference to natural theology 'which is regarded simply as a preparation' $(\mathrm{CD}, 2,1,101)$. For 'it is not to be disputed that the biblical witnesses do appeal to the witness of man in the cosmos' $(\mathrm{CD}, 2,1$, 102). But his conclusion is that 'the witness of man in the cosmos does not come about 
independently, but in utter coordination with and subordination to the witness of the speaking and acting of God in the people and among the men of the people of Israel' $(\mathrm{CD}, 2,1,108)$. For 'the biblical witnesses point also to man in the cosmos in order to interpret the revelation of God in its necessary and compulsive direction and relation to the one to whom it is addressed' (CD, 2, 1, 111). So the witness of man in the cosmos is a witness that has no genuine independence of the revelation of God. It is a witness that reflects the revelation and action of God already taking place. And where the revelation is revelation about human beings rather than about God this is in order to show how the revelation of God ought to be interpreted.

These statements show that some of the features of human beings which might be grasped by other methods than revelation, for example by the methods of empirical theology, are in a position to illustrate the general principles found in revelation. In the words of Torrance, 'Barth claims that, properly understood, natural theology is included within revealed theology'. ${ }^{16}$ So natural theology is not an enemy of the theology of revelation but submerged within it. This is particularly apparent in Barth's discussion of the key texts in Romans 1.18ff. His contention is that these texts occur within the immediate context of the declaration of the divine revelation (apokalupsis) of the Gospel spoken of in Romans 1.15,16. So those Jews and Gentiles who discern God in creation are not Jews and Gentiles in general but rather those who have been 'confronted with the divine apokalupsis of the Gospel' (CD, $2,1,119)$. Whatever natural theology gives to these people would not have been given had the Gospel been withheld.

The Pauline argument in Romans 1 need not be read in the way advocated by Barth. Dunn argues that 'there is an innate rapport between the divine and the human because the divine 
logos immanent throughout the world is immanent also in man as the power of reason' ${ }^{17}$ Creaturely rationality can grasp the creator's rational creativeness, implying some form of natural theology.

Torrance's own account of natural theology is distinct from Barth's. Whereas Barth objected to a separate witness to God that might contradict or compromise revelation, Torrance moves natural theology 'into the domain of systematic theology' so that it can be 'developed as a complex of rational structures ${ }^{, 18}$ within the fabric of revealed theology. Natural theology is natural in a new way because it is adapted to its proper object which is 'God in self-revealing interaction with us in space and time'. ${ }^{19}$ Natural theology's method is adapted to the physical conditions under which God is revealed, an adaptation characteristic of science.

Furthermore, it is scientific in the sense that it is a rigorous enterprise and in the sense that it is enacted under the double conditions of the reality of God and the constraints of space and time, even if space and time are themselves, after Einstein, recognised as inter-connected. God's self-revelation takes place to human beings within the world and the intelligibility of the world is itself part of the disclosure. It follows that, as natural science explains and reconceptualises the world in new ways, so theological understanding of God's relation to this world must also change.

Indeed alternative natural theologies are already coming into existence, natural theologies that begin from a non-Christian position but which are drawn into existence by the extraordinary intricacies and complexity of the universe. For example Davies 'strays into pantheism' on one side while, on the other, postulating the existence of a God who looks more like a pagan demiurge than the traditional Judaeo-Christian God. ${ }^{20}$ While, by contrast, Hoyle seeks to 
provide an account of the origin of human race by reference to insemination by alien spores. Such variations are indicative of the possibility of constructing more than one metaphysical account on the basis of the same scientific view of the world.

Equally supportive of empirical theology is the analogy drawn by Augustine between the Trinity and human beings. Human beings, as made in the image of God, must bear a Trinitarian imprint. Throughout the text of De Trinitate, Augustine draws a series of parallels between the nature of human beings and the nature of Trinity. For example in book 13 there is in the human mind a kind of trinity since any recollection of words committed to memory contains both the sounds of those words and the shape of them in written form and then, when recollected, sound and shape are combined. A series of analogies make the same point, and the point is made because Augustine presumes that God leaves vestiges of himself within creation, and especially within human beings.

\section{The application of empirical theology}

On the basis of the foregoing, how is empirical theology to be conceived and practised?

A series of choices must be made. First, about whether theology in its entirety is an art or a science. Is it hermeneutical, expressive and essentially non-realist or in some sense fixed by its unchanging subject matter and therefore normative, logical and epistemologically unique? Second, about the location of empirical theology, either as the practical and applied section within each of the disciplines comprising the whole field of theology or as an intermediate discipline utilising an empirical tool box to prepare every other theological discipline for its handling within practical theology. Third, about the possible location of empirical theology in a special relationship with natural theology, where natural theology is located inside 
revealed theology. Fourth, about whether to accept without alteration the intradisciplinary approach advocated by Nijmegen and worked out in detail by van der Ven. Each of these choices has an impact on the practice of empirical theology and its practitioners need to be clear about where they are placing it and the criteria by which pieces of work are judged to be (a) empirically satisfactory and (b) theologically satisfactory.

Nevertheless, however these choices are made, there appears to be no reason in principle to deny that social science methods may be adopted within the family of methods already at home within the general field of theology. It would be absurd, for instance, to accept sophisticated historiography in support of historical theology while denying the best social science methods in support of empirical theology.

Van der Ven has given a series of illustrations concerning the application of empirical theology. His most detailed account concerns the relationship between concepts of God and of theodicy. His exploration of this relationship made use of the steps of theological reflection that he recommends as well as an extremely thorough and impressive piece of empirical work using variables operationalised from the theological reflection. By beginning and ending with theology he has attempted a contribution to theological understanding. On the other hand, Kay and Francis in presenting an account of interdisciplinary work as a whole, have not shown exactly how the theological element of in any investigation might be related to the empirical phase. ${ }^{21}$ But they would accept and agree with the general notion of operationalisation. In an example given by Kay variables within a church-related situation were tested and the theological contribution to the testing concerns the identification of which variables were likely to be salient. ${ }^{22}$ By taking a theological account, in this case of church growth, and subjecting it to empirical exploration, it was possible to discover whether the 
theological model had any empirical reality. Francis, in a series of studies on church schools, has begun with the presumed theology for establishing and maintaining these schools and then has tested outcomes in the lives of their pupils. ${ }^{23}$ Here also a theological model, albeit often tacit, was tested against empirical reality. So interdisciplinary work of this kind has served to test theological assumptions rather than to contribute to new theological analyses or accounts. And the reason why no attempts were made by this (British) school of empirical theology is that there does appear to be considerable disjunction between the tight methodology of empirical work and the much looser and discursive nature of theological discourse. The British took the view that their testing of existing theological models largely spoke for itself and that, in any case, there was no obvious methodological bridge back from the results of empirical test to the uncertain conditions or assumptions that had first generated the theological model.

Torrance's discussion of natural theology does have a bearing on the functioning of empirical theology. If, as argued, empirical theology has a special relationship to natural theology then we are likely to see natural theology influenced by the processes and concepts of the scientific community. In this way traffic begins to flow from the scientific community to natural theology and from natural theology to empirical theology. We may anticipate listening to and constructing theological explanations from probabilistic or causal mechanisms within the physical world, from the nature of time, from the implications of mapping the genome, from mind-body experimentation, from embryo research, and so on. In this way new categories and concerns may arrive within theology as a field -- that is, across most of its disciplines. Some ideas will arrive by percolating through empirical theology and others through philosophy and, even, liturgy and popular culture. Torrance's notion that natural theology can lead to new rational structures within systematic theology is part of this larger picture. 
Theology itself begins to change its grand classificatory concepts and to reorganise itself to face the world of the third millennium.

Finally, and quite different, is the apologetic task to which natural theology, and therefore empirical theology, may be applied. The credibility of natural theology, the argument for the existence of God on the basis of the uniformities of the natural world, has fluctuated since St Paul, Aquinas and Paley. It has been challenged in the $19^{\text {th }}$ century and then towards the end of the $20^{\text {th }}$ century underwent a resurgence, particularly as the complex nature of the universe was shown to exist not only at the macro-level but that the micro-level and in terms of the constants governing the original expansion from the singularity after the big bang. This resurgence of natural theology based upon a consideration of the physical world may yet have its counterpart in respect of the social and psychological world.

The social and psychological world of human beings is predicated upon the need to protect and nurture babies - this imperative ensures the survival of the species. Additionally, humans have a prolonged period of vulnerable childhood. Rich and early contact with other human beings is necessary to subsequent cognitive and emotional growth, especially in harnessing the communicative and ratiocinative possibilities of language and in laying down the social and familial bonds that prevent pathological behaviour. Such formative experiences within the early stages of human life are also likely to have other purposes. They are likely to be connected with faith, where faith is defined as an attitude of dependence and trust. For this reason, then, empirical theology may begin to investigate the processes that give rise to normal human development and to argue on the basis of these processes for the existence of a God who put them in place. ${ }^{24}$ The design of these processes may be conducive to an understanding of the work of God. 
${ }^{1}$ Paul Hirst, Knowledge and the Curriculum, (London, Routledge and Kegan Paul, 1974); Michael W Eysenck and M T Keane, Cognitive Psychology ( $3^{\text {rd }}$ edition), (Hove: UK, Lawrence Erlbaum Associates, 1995).

${ }^{2}$ Duncan B Forrester, Truthful Action, (Edinburgh, T \& T Clark, 2000), p. 23.

${ }^{3}$ Johannes van der Ven, Practical Theology: an empirical approach, (Kampen, The Netherlands: Kok Pharos, 1993), p. 2.

${ }^{4}$ Johannes van der Ven Practical Theology: an empirical approach, (Kampen, The Netherlands: Kok Pharos, 1993), p. 6.

5 Johannes van der Ven Practical Theology: an empirical approach, (Kampen, The Netherlands: Kok Pharos, 1993), pp. 29, 26, 30, 103.

${ }^{6}$ E.g. Helmut Reich, 'Can one really understand Christian doctrine?' British Journal of Religious Education, 16, (1994), pp. 114-126.

${ }^{7}$ William K Kay and Leslie J Francis, 'The Seamless Robe: interdisciplinary enquiry in religious education', British Journal of Religious Education 7.2, (1985), pp. 64-67.

${ }^{8}$ Leszek Kolakowski, Positivist Philosophy, (Harmondsworth: Penguin 1972).

${ }^{9}$ Karl R Popper, Unended Quest, (Glasgow, William Collins (4 ${ }^{\text {th }}$ impression), 1978).

${ }^{10}$ E.g. Duncan B Forrester, Truthful Action, (Edinburgh: T \& T Clark, 2000), p. 26.

${ }^{11}$ Karl Barth, Church Dogmatics 2.1: the doctrine of God, G W Bromiley and T F Torrance (eds), (Edinburgh: T \& T Clark, 1957).

${ }^{12}$ Heisenberg; pace Popper, ibid., p. 95.

${ }^{13}$ Roy Porter, Enlightenment: Britain and the creation of the modern world, (London: Allen Lane The Penguin Press, 2000), e.g. p. 142.

${ }^{14}$ Richard Holloway, once Bishop of Edinburgh, made precisely this art/science distinction in an interview and claimed that theology, contrary to other views, is an art. (BBC radio 4, 26 August, 2001).

${ }^{15}$ Paul Avis, The Methods of Modern Theology: the dream of reason, (Basingstoke: Marshall Pickering, 1986).

${ }^{16}$ Tom F Torrance, The Ground and Grammar of Theology, (Belfast: Christians Journals Ltd., 1980), p. 91

${ }^{17}$ James D G Dunn, Romans 1-8, (Dallas, Texas: Word Books 1988), p. 71.

${ }^{18}$ Alister E McGrath, Science and Religion, (Oxford: Blackwell, 1999), p.132.

${ }^{19}$ Tom F Torrance, Reality and Scientific Theology, (Edinburgh: Scottish Academic Press), p. 39.

${ }^{20}$ David A Wilkinson, 'The revival of natural theology in contemporary cosmology', Science and Christian Belief, 2 (1990), pp. 95-115.

${ }^{21}$ William K Kay and Leslie J Francis, 'The Seamless Robe: interdisciplinary enquiry in religious education', British Journal of Religious Education 7.2, (1985), pp. 64-67.

${ }^{22}$ William Kay, 'Pentecostalism: charismata and church growth', in L.J. Francis (ed), Sociology, Theology and Curriculum, (London: Cassell, 1999), pp. 135-144.

${ }^{23}$ E.g. Leslie J Francis, 'Denominational schools and pupil attitudes towards Christianity', British Educational Research Journal, 12, (1980) pp. 145-52; Leslie J Francis and Marian Carter, 'Church aided secondary schools, religious education as an examination subject and pupil attitude towards religion', British Journal of Educational Psychology, 50, (1980) pp. 297-300; Leslie J Francis and Josephine Egan, 'Catholic schools and the communication of faith', Catholic School Studies 60, 2, (1987) pp. 27-34; Leslie J Francis and A Jewell (1992), 'Shaping adolescent attitude towards the church: comparison between Church of England and county secondary schools', Evaluation and Research in Education, 6, (1992), pp. 13-21.

${ }^{24}$ Peter L Berger, A Rumour of Angels, (Harmondsworth: Penguin, 1970). 